\title{
Teachers' Professional Development Level across Cohort of Generations in Malaysia
}

\author{
Mohd Faiz Mohd Yaakob
}

Dr., Universiti Utara Malaysia, Malaysia,mohd.faiz@uum.edu.my

\section{Yahya Don}

Universiti Utara Malaysia, Malaysia, d.yahya@uum.edu.my

\section{Ibrahim Sufi}

Serambi Mekkah Universiti, Indonesia, himsufi@gmail.com

\section{Mat Rahimi Yusof}

Universiti Utara Malaysia, Malaysia, mrahimiy@uum.edu.my

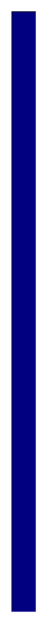

\begin{abstract}
The school organization consists of a multi generation teacher community which would mean professional development programs of one-size fits all should change towards fulfilling the needs of all teachers in the effort to strengthen the quality of education. This is because each generation has different ways of accepting changes. Therefore, this study aims to identify the different levels of teacher professional development across the cohort of generations such as the Baby Boomers, Gen X and Gen Y. The quantitative study used survey method through questionnaire where the sample consisted of 300 teachers in Kelantan was selected using purposive sampling technique. Data collection method was primary data with quantitative and analysis techniques using descriptive analysis. The findings show that there was a significant difference in the level of teacher professional development across the cohort of generations. The results of this study can help school management to design a more appropriate professional development approach for all cohorts of teacher generation. This coordination is expected to enhance the professionalism of every teacher towards realizing the ministry's aspiration in upholding the quality of teaching and quality education in Malaysia.
\end{abstract}

Keywords: professional development, generation, baby boomers, gen x, gen $\mathrm{y}$

\section{INTRODUCTION}

The aim of the Malaysia education is to reach the top one-third best education system among other countries in the world. According to the Malaysian Education Development Plan (PPPM) 2013-2025, one of the steps taken to achieve this goal is to

Citation: Yaakob, M. F. M., Don, Y., Sufi, I., \& Yusof, M. R. (2020). Teachers' Professional Development Level across Cohort of Generations in Malaysia. International Journal of Instruction, 13(4), 443-456. https://doi.org/10.29333/iji.2020.13428a 
empower teachers' professional development. Features of teacher professionalism need to be systematically and continuously developed to ensure that every policy of education is implemented effectively and thus has a significant impact on student growth. However, the process of globalization that is so prevalent in today's world scenario has made people's culture, attitudes and lifestyles change from one generation to another. As a result, the role of teachers becomes increasingly challenging. These problems stand in the way of obtaining excellent performance for teachers.

The current population of teachers is multi generation, largely dominated by the generations of Baby Boomers, Gen X and Gen Y. This situation results in various ranges of behaviors, tendencies and acceptance of new knowledge and skills. Baby Boomers teachers (born 1946-1964) tend to share experiences and Gen X teachers (born 1964-1982) are more towards hands-on approach while Gen Y teachers (1982 - 1994) prefer problem-solving approach (Eller \& Eller, 2017). Therefore, the implementation of teacher professional development should be in line with the multi generation teachers' acceptance. This is to enhance the teachers to be on par with the latest generation of students who are said to be extremely exposed to technological evolution.

\section{The Challenges of Implementing Teacher Professional Development}

The success of a school organization depends on the effectiveness of its management system in providing a strategic plan for teacher professional development. While there is a lot of good training service for teachers, it is still not possible to provide teachers who can withstand all of the challenges they will face throughout their careers. (OECD, 2009). It should be noted that school organizations at present have multi generation teachers. This is why school management needs to change from the "one-size fits all" principle of a professional development program or activity to approaches that meet the needs of every generation of teachers (Higginbottom, 2016). It is the responsibility of the school management to understand and act effectively in the professional development of teachers. This is because the ministry's ambition is towards a quality education system (PPPM 2013-2025). Therefore, it is imperative to understand the target of professional development on each generation of teachers so as to develop a mechanism that meets the needs of each teacher. This problem has received limited attention in Malaysian literature.

According to Breiburd (2018), the problems that often arise in the implementation of professional development are due to the design being drawn to be traditional from beginning to end, which is an approach that involves formal printed materials and onesided lecture methods only. This paradigm has to change where management needs to consider the design of the professional development mechanism by looking at the existing multi generation in order to make the delivery and communication more effective in achieving the goals and objectives of the program (Hunt \& Tucciarone, 2011). Otherwise, the implementation of professional development will be ineffective and futile. Among the negative side effects are that teachers do not give a good and sincere commitment to the teaching task (Yang et al., 2018), generation $\mathrm{X}$ and $\mathrm{Y}$ teachers will be bored because the knowledge they can obtain through internet searches is more current and creative (Behrstock \& Clifford, 2009), while Baby Boomers 
teachers reject the changes that they find difficult to follow because they are said to be more experienced and most importantly; the collaboration between teachers will also be affected by the lack of understanding with each other and thus becomes a hindrance to the goal of the school (Carter, 2018).

Therefore, in order to make professional development more effective, school management needs to consider the generation aspect among teachers so that the management is able to design training opportunities that cover all levels of teacher generation.

The most powerful step that can improve student achievement is through professional learning (Hazri et. al, 2014). For this reason, students need effective and quality teachers in teaching to help students develop a variety of skills emphasized in the $21 \mathrm{st}$ century. At the same time, in anticipation of student achievement, the diversity in the student generation has also increased. This means that professional development of teachers must also be effective in keeping up with the student's developmental situation.

\section{METHOD}

The aim of this study is to discuss the differences in the level of teacher professional development based on the Baby Boomers, Gen X and GenY generation. In this regard, the results of this research are important because the effectiveness of professional development activities conducted in schools is seen from the perspective of teacher acceptance based on the tendency of the teacher generation itself.

Quantitative research in the form of survey was the research design used in conducting this study. A total of 300 secondary school teachers around Pasir Puteh district were selected using the purposive sampling technique. Table 1 shows study sample based on generation.

Table 1

Sample based on Generation

\begin{tabular}{lll}
\hline Number & Generation Cohort & Study Sample \\
\hline 1 & Baby Boomers & 100 \\
2 & X & 100 \\
3 & Y & 100 \\
& Total & 300 \\
\hline
\end{tabular}

The instrument used consisted of two sections, Part A and Part B. Part A focused on to demographic information while Part B contained questions that measure the level of teacher professional development adapted from the OECD (2009) and Q4TE (Grohmann \& Kauffeld, 2013). The respondents' perceptions were measured using Likert scale of five levels of agreement.

\section{Data Analysis Techniques}

There are several types of data analysis techniques that exist in research. In this study, descriptive analysis was used to complete data sample of summarized numerical data. Mean and standard deviation for continuous data whereas percentage and frequency for categorical data. 


\section{FINDINGS}

\section{Teacher Involvement in Professional Development Activities}

To determine the respondents' level of involvement in professional development activities, mean and standard deviation (SD) analysis was performed as shown in Table 2 below. The number of days of professional development engagement most attended by teachers, namely professional development engagements over 10 days is as follows: Gen Y teachers (15\%), followed by Baby Boomers (13\%) and Gen Y (5\%). Courses or workshops were the most popular type of activities for Baby Boomers (100\%) and Gen $X(91 \%)$ teachers, while informal activities were the most common type of activities attended by Gen Y teachers ( $81 \%)$, in enhancing their professionalism.

In terms of professional development activities that teachers favor, in Table 2 below, the findings indicate that Baby Boomers teachers were more involved in educational seminars $(74 \%)$, Gen $\mathrm{X}$ teachers attended courses or workshops $(81 \%)$, while Gen $\mathrm{Y}$ teachers preferred to be involved in informal activities (78\%). For professional development activities, academic qualification programs were not liked by Baby Boomers teachers $(0 \%)$ and less liked by Gen X teachers $(12 \%)$ and Gen Y teachers $(19 \%)$. Baby Boomers teachers also showed no liking to online activity $(0 \%)$ while Gen $\mathrm{X}$ teachers showed less interest in research activity $(6 \%)$.

Table 2

Percentage of Teacher involvement in Professional Development Activities

\begin{tabular}{|c|c|c|c|}
\hline \multirow[t]{2}{*}{ Involvement in Professional Development Activities } & \multicolumn{3}{|l|}{ Percentage $(\%)$} \\
\hline & $\begin{array}{l}\text { Baby Boomers } \\
(\mathrm{n}=100)\end{array}$ & $\begin{array}{l}\text { Gen X } \\
(\mathrm{n}=100)\end{array}$ & $\begin{array}{l}\text { Gen Y } \\
(\mathrm{n}=100)\end{array}$ \\
\hline \multicolumn{4}{|l|}{$\begin{array}{l}\text { Within } 10 \text { months, the number of days involved in } \\
\text { professional development activities was: }\end{array}$} \\
\hline - 1- 5 days & 40 & 52 & 53 \\
\hline - $6-10$ days & 47 & 43 & 29 \\
\hline - $>10$ days & 13 & 5 & 15 \\
\hline \multicolumn{4}{|l|}{ Within 10 months, the type of activity attended } \\
\hline - Courses/Workshops & 100 & 91 & 70 \\
\hline - Educational Seminar & 27 & 24 & 33 \\
\hline - Academic Qualification Program & 7 & 3 & 0 \\
\hline - Observations on other schools & 28 & 16 & 0 \\
\hline - Research Activity & 14 & 6 & 5 \\
\hline - Mentoring and Peer Observation & 48 & 61 & 73 \\
\hline - Academic Reading & 47 & 38 & 36 \\
\hline - Informal Discussion & 81 & 78 & 81 \\
\hline - Online Activity & 28 & 32 & 52 \\
\hline \multicolumn{4}{|l|}{ Interest in the type of staff development activities } \\
\hline - Courses/Workshops & 61 & 81 & 56 \\
\hline - Educational Seminar & 74 & 41 & 39 \\
\hline - Academic Qualification Program & 0 & 12 & 19 \\
\hline - Observations on other schools & 19 & 49 & 29 \\
\hline - Research activity & 21 & 6 & 29 \\
\hline - Mentoring and Peer Observation & 14 & 36 & 34 \\
\hline - Academic Reading & 54 & 24 & 38 \\
\hline - Informal Discussion & 47 & 62 & 78 \\
\hline - Online Activity & 0 & 23 & 42 \\
\hline
\end{tabular}




\section{Knowledge Level of Teacher Professional Development}

Table 3 shows the mean scores for teachers' perceptions of professional development knowledge by generation. Overall, it shows that the perceptions of all generations of teachers are at a high level. This finding is in line with a study conducted by Jayakaran et.al (2011) on teachers in Malacca who found that teachers' knowledge of professional development is high. In this study, Baby Boomers, Gen X teachers and Gen Y teachers showed high level for each item, with the exception of Gen Y teachers showing moderately high level for item 4 'know all types of activity that can be categorized as professional development' (Mean $=3.80, \mathrm{SD}=.6667$ ) and item 5 'professional development activities can help students' problems' $($ Mean $=3.99, \mathrm{SD}=.7035)$.

From a comparative standpoint, Baby Boomers teachers showed the highest mean scores for each item in their professional development, while Gen Y teachers showed the lowest mean scores among generations. On the whole it can be said that the Baby Boomers and Gen X teachers understood the concept of professional development better than the Gen Y teachers. The one-way ANOVA analysis shown in Table 4, found that there were significant differences in mean scores on professional development based on cohort generation, $\mathrm{F}(2,297)=14.673 ; \mathrm{p}<.000)$.

Table 3

Teachers' Level of Professional Knowledge

\begin{tabular}{|c|c|c|c|c|c|}
\hline Items & & Gen & $\mathrm{N}$ & Mean & SD \\
\hline \multirow[t]{3}{*}{1} & \multirow{3}{*}{$\begin{array}{l}\text { Knew the importance of professional } \\
\text { development. }\end{array}$} & BB & 100 & 4.40 & .4924 \\
\hline & & $X$ & 100 & 4.30 & .4606 \\
\hline & & Y & 100 & 4.33 & .6522 \\
\hline \multirow[t]{3}{*}{2} & \multirow{3}{*}{$\begin{array}{l}\text { Knew that professional development has } \\
\text { to be conducted continuously. }\end{array}$} & BB & 100 & 4.59 & .4943 \\
\hline & & $X$ & 100 & 4.31 & .5806 \\
\hline & & Y & 100 & 4.38 & .4878 \\
\hline \multirow[t]{3}{*}{3} & \multirow{3}{*}{$\begin{array}{l}\text { Knew that professional development can } \\
\text { improve the level professionalism and } \\
\text { teacher quality. }\end{array}$} & BB & 100 & 4.66 & .4761 \\
\hline & & $X$ & 100 & 4.33 & .5329 \\
\hline & & Y & 100 & 4.31 & .5631 \\
\hline \multirow[t]{3}{*}{4} & \multirow{3}{*}{$\begin{array}{l}\text { Knew all the activities / programs that can } \\
\text { be categorized as professional } \\
\text { development. }\end{array}$} & BB & 100 & 4.39 & .4902 \\
\hline & & $X$ & 100 & 4.11 & .5104 \\
\hline & & $\mathrm{Y}$ & 100 & 3.80 & .6667 \\
\hline \multirow[t]{3}{*}{5} & \multirow{3}{*}{$\begin{array}{l}\text { Knew that the professional development } \\
\text { activities can help students' learning } \\
\text { problems. }\end{array}$} & BB & 100 & 4.40 & .4924 \\
\hline & & $X$ & 100 & 4.17 & .4935 \\
\hline & & $\mathrm{Y}$ & 100 & 3.99 & .7035 \\
\hline
\end{tabular}


Table 4

Difference in Levels of Teacher Professional Knowledge based on Cohorts of Generation

\begin{tabular}{lllllllll}
\hline Construct & Generation & N & Mean & SD & df1 & df2 & F & Sig. \\
\hline Knowledge & BB & 100 & 4.49 & .3911 & 2 & 297 & 14.673 & .000 \\
& X & 100 & 4.22 & .3904 & & & & \\
& Y & 100 & 4.16 & .5316 & & & & \\
\hline
\end{tabular}

\section{Level of Teacher Professional Development}

Descriptive analysis involving mean and standard deviation was conducted to examine the differences in teacher professional development levels across cohorts of generation as shown in Table 5. This was to see the short-term impact (response and learning) and long-term (organizational behaviour and organizational outcomes) of each teacher. Mean score analysis of response was based on self-satisfaction sub-scale which showed a high level for all items for Baby Boomers and Gen X teachers compared to Gen Y teachers which were moderately high level. The usage sub-scale indicated that all generations of teachers showed high mean scores on all items except for Gen Y teachers who perceived that the professional development activity contributed to students' performance, at a moderately high level (Mean $=3.86, \mathrm{SD}=.5690)$.

The mean score analysis for learning based on three items displayed Baby Boomers and Gen X teachers showed high levels for each item, whereas Gen Y teachers showed two items at moderately high level that is, in item 7 on content improvement (Mean $=3.91$, $\mathrm{SD}=.4287$ ) and item 9 on the correlation between current and previous activity (Mean $=3.80 ; \mathrm{SD}=.6817)$. For items in the behavioral constructs applied in teacher professional development practice, the mean score for Baby Boomers and Gen $\mathrm{X}$ teachers were at high level for all items, whereas the Gen Y teachers showed a mean score at a moderately high level for all items.

For Organizational Outcomes items, Baby Boomers teachers showed high mean scores for all items, while Gen $X$ teachers showed high mean scores on all items except item 17, which was helpful in planning effective professional development plans, at a moderately high level $($ Mean $=4.00, \mathrm{SD}=.4714)$. For Gen $\mathrm{Y}$ teachers all of the items in this construct were also at a moderately high level. 
Table 5

Level of Teacher Professional Development based on Cohorts of Generation

\begin{tabular}{|c|c|c|c|c|c|c|}
\hline Scale & & Items & Gen & $\mathrm{N}$ & Mean & SD \\
\hline \multirow[t]{18}{*}{ Response } & \multirow{9}{*}{$\begin{array}{l}\text { Self } \\
\text { satisfaction }\end{array}$} & 1. Professional development & BB & 100 & 4.20 & .4020 \\
\hline & & activities remain positively in our & $\mathrm{X}$ & 100 & 4.09 & .4734 \\
\hline & & memory. & Y & 100 & 3.90 & .4381 \\
\hline & & 2. Enjoyed the professional & BB & 100 & 4.20 & .5505 \\
\hline & & development activities. & $\mathrm{X}$ & 100 & 4.05 & .4578 \\
\hline & & & $\mathrm{Y}$ & 100 & 3.71 & .5558 \\
\hline & & 3. Always be involved in all & BB & 100 & 4.06 & .5829 \\
\hline & & professional development & $\mathrm{X}$ & 100 & 4.00 & .4714 \\
\hline & & activities organized. & $\mathrm{Y}$ & 100 & 3.86 & .6516 \\
\hline & \multirow[t]{9}{*}{ Usage } & 4. Professional development & BB & 100 & 4.39 & .4902 \\
\hline & & activities were very helpful. & $\mathrm{X}$ & 100 & 4.26 & .4845 \\
\hline & & & $\mathrm{Y}$ & 100 & 4.01 & .6276 \\
\hline & & 5. Participation in professional & BB & 100 & 4.45 & .5000 \\
\hline & & development activities was very & $\mathrm{X}$ & 100 & 4.28 & .4513 \\
\hline & & beneficial. & $\mathrm{Y}$ & 100 & 4.06 & .5829 \\
\hline & & 6. Activities in professional & BB & 100 & 4.20 & .4020 \\
\hline & & development contributed to & $\mathrm{X}$ & 100 & 4.07 & .4768 \\
\hline & & student performance. & $\mathrm{Y}$ & 100 & 3.86 & .5690 \\
\hline \multirow{9}{*}{ Learning } & \multirow{9}{*}{ Knowledge } & 7. Knew more about the contents & BB & 100 & 4.26 & .5795 \\
\hline & & from each training session & $\mathrm{X}$ & 100 & 4.18 & .5390 \\
\hline & & compared to before. & $\mathrm{Y}$ & 100 & 3.91 & .4287 \\
\hline & & 8. Learnt many new things in & BB & 100 & 4.27 & .5835 \\
\hline & & professional development & $\mathrm{X}$ & 100 & 4.18 & .5001 \\
\hline & & activities. & $\mathrm{Y}$ & 100 & 4.15 & .4578 \\
\hline & & 9. There was a correlation & BB & 100 & 4.12 & 6241 \\
\hline & & between current and previous & $\mathrm{X}$ & 100 & 4.01 & .5024 \\
\hline & & year's activities. & $\mathrm{Y}$ & 100 & 3.80 & 6817 \\
\hline \multirow[t]{9}{*}{ Behaviour } & \multirow{9}{*}{$\begin{array}{l}\text { Practice } \\
\text { application }\end{array}$} & 10. Frequently used knowledge & BB & 100 & 4.13 & .7338 \\
\hline & & gained in professional & $\mathrm{X}$ & 100 & 4.03 & .4596 \\
\hline & & development activities. & $\mathrm{Y}$ & 100 & 3.84 & .6312 \\
\hline & & 11. Successfully applied the & BB & 100 & 4.26 & .5795 \\
\hline & & content of professional & $\mathrm{X}$ & 100 & 4.02 & .4259 \\
\hline & & $\begin{array}{l}\text { development activities in daily } \\
\text { work. }\end{array}$ & $\mathrm{Y}$ & 100 & 3.91 & .5336 \\
\hline & & 12. Focused on the curriculum and & BB & 100 & 4.06 & .5829 \\
\hline & & how students learn. & $\mathrm{X}$ & 100 & 4.03 & .4596 \\
\hline & & & $\mathrm{Y}$ & 100 & 3.87 & .4640 \\
\hline \multirow{15}{*}{$\begin{array}{l}\text { Organizational } \\
\text { outcomes }\end{array}$} & \multirow[t]{6}{*}{ Individual } & 13. More satisfied with my own & BB & 100 & 4.26 & .5795 \\
\hline & & work. & $\mathrm{X}$ & 100 & 4.05 & .4794 \\
\hline & & & $\mathrm{Y}$ & 100 & 3.86 & .4718 \\
\hline & & 14. Work performance has & BB & 100 & 4.26 & .5795 \\
\hline & & improved through the application & $\mathrm{X}$ & 100 & 4.08 & .4188 \\
\hline & & of content. & $\mathrm{Y}$ & 100 & 3.95 & .3890 \\
\hline & \multirow[t]{9}{*}{ Organization } & 15. Use of professional & BB & 100 & 4.46 & .5009 \\
\hline & & development activities content has & $\mathrm{X}$ & 100 & 4.05 & .4578 \\
\hline & & facilitated the work process. & $\mathrm{Y}$ & 100 & 3.81 & .5064 \\
\hline & & 16. Organizational culture has & BB & 100 & 4.20 & .5505 \\
\hline & & improved because of professional & $\mathrm{X}$ & 100 & 4.12 & .4981 \\
\hline & & development activities. & $\mathrm{Y}$ & 100 & 3.83 & .5870 \\
\hline & & 17. Helpful in planning effective & BB & 100 & 4.18 & .6572 \\
\hline & & professional development plans. & $\mathrm{X}$ & 100 & 4.00 & .4714 \\
\hline & & & $\mathrm{Y}$ & 100 & 3.70 & .6435 \\
\hline
\end{tabular}

Overall, Baby Boomers and Gen X teachers showed a high level for all constructs, namely, the response, learning, behavior and organizational outcomes of the accepted 
professional development. Meanwhile, Gen Y teachers showed moderately high level in all constructs of the professional development. ANOVA analysis revealed that these three generations of teachers had significant mean score differences $(p<.000)$ across all constructs of the professional development, as shown in Table 6 below.

Table 6

Different Constructs of Teacher Development by Cohorts of Generation

\begin{tabular}{lllllllll}
\hline Construct & Generation & N & Mean & SD & df1 & df2 & F & Sig. \\
\hline Response & BB & 100 & 4.25 & .4261 & 2 & 297 & 18.878 & .000 \\
& X & 100 & 4.13 & .3642 & & & & \\
Learning & Y & 100 & 3.90 & .4310 & & & & \\
& BB & 100 & 4.22 & .5022 & 2 & 297 & 9.683 & .000 \\
& X & 100 & 4.12 & .4094 & & & & \\
Behavior & Y & 100 & 3.95 & .3640 & & & & \\
& BB & 100 & 4.15 & .5791 & 2 & 297 & 9.997 & .000 \\
& X & 100 & 4.03 & .3406 & & & & \\
Organizational & Y & 100 & 3.87 & .3539 & & & & \\
Outcomes & X & 100 & 4.27 & .4801 & 2 & 297 & 24.897 & .000 \\
& Y & 100 & 4.06 & .3696 & & & & \\
\hline
\end{tabular}

\section{DISCUSSION}

The result of the study showed that Gen $\mathrm{Y}$ teachers were more likely to be involved in professional development activities than Baby Boomers and Gen $\mathrm{X}$ teachers. This finding is in line with a study conducted by the Teaching and Learning International Survey (TALIS, 2009) in which average teachers who are most involved in professional development programs are teachers under the age of 30. This shows that less experienced teachers need to receive more professional development than experienced teachers. No matter how effective pre-service training has been, it cannot be expected to provide teachers with all the challenges they will face throughout their career (TALIS, 2009). Therefore, the education system should always strive to provide teachers with opportunities to enhance their profession in maintaining high standards of teaching and staff quality teaching (PPPM, 2013-2025).

The finding also showed that the types of professional development activities available in schools were in the form of courses, workshops and informal activities. This finding is in line with studies by TALIS (2009) and; Mohd Faeez et.al (2017) where school activities that were commonly conducted were training programs such as courses, workshops and informal dialogue sessions to enhance knowledge and skills as they are seen to have a positive impact on past research. A study by Hugman (2005) stated that courses and workshops were most frequently conducted by organizations because of time and cost effective as they could involve many participants at one time. However, teacher's' acceptance of the need to attend training programs depends on each individual (Klassen \& Chiu, 2010).

The findings of the study showed that the activities that teachers were interested in were different from the training programs provided. Baby Boomers teachers were more 
interested in seminar-related activities, while Gen $\mathrm{X}$ teachers were more likely to attend courses or workshops, and Gen Y teachers preferred to engage in informal activities. According to Eller and Eller (2017) in the process of professional development, Baby Boomers teachers love to share their perspectives and experiences. Therefore, it is seen as appropriate for this group to have activities that include sharing of things and enable them to argue and voice their opinions.

Gen X teachers are seen as needing guidance at an early stage in their careers as they are still looking for a balance between career and life (Desai, 2016). As such, attending courses or workshops is one of the instructional activities and guidance in learning something that can help them focus more on their career. A study conducted by Udemy Online (2018) shows that Gen Y is more likely to learn informally individually through online, book reading and so on. This is because Gen Y teachers are more exposed to the latest technology than the Baby Boomers and Gen X teachers. The influence and impact of technology on interactions with individuals and expectations about the flow of information can be a conflict between Gen $\mathrm{Y}$ teachers and Baby Boomers administrators. In addition, Gen Y teachers prefer to acquire information immediately and only communicate via text message, do not want to be connected through the hierarchy and reject top-down communications or alerts that are said to be traditional and slow (Valcour, 2013). Further, Gen Y teachers are more likely to engage in informal activities.

Consecutively, the research results showed that Baby Boomers teachers were less interested in online activity and academic qualification programs. This finding is consistent with a study by Seipert and Baghrust (2014) that showed that Baby Boomers principals were less interested and less motivated in technology-driven programs. However, the findings of this study indicated that Baby Boomers were ready to accept changes in technology. The study by James et.al (2007) also shows that Baby Boomers are not interested in improving academic achievement and quality. This is because this group has a strong presence in life and career and thus holds to the principle that experience is more beneficial than theory (school of hard knocks).

For Gen $\mathrm{X}$ teachers, the findings show that research was a less favorable professional development activity. This shows that Gen X workers prefer to get information through their own skills and trust their own judgment to perform their tasks freely and flexibly (Seyers, 2007). This is because Gen X is a more independent, resilient and adaptable group. The combination of characteristics in Gen X and technological literacy can help Gen X develop its skills and knowledge freely.

The findings indicate that Gen Y teachers were less interested in academic qualification programs in professional development. Zemke et. al (2000) stated that Gen Y teachers have a higher education qualification or professional training background. Most Gen Ys have at least a diploma or degree in college or university (Schroer, 2008). Therefore, Gen Y teachers usually tend to stay imperturbable in the workplace without realizing that academic qualification program is one of the activities that can enhance their professionalism. 
The level of teacher professional development knowledge indicates that Baby Boomers teachers have a solid basic knowledge of professional development concepts compared to Gen $\mathrm{X}$ and Gen $\mathrm{Y}$ teachers. Although Gen $\mathrm{X}$ and Gen $\mathrm{Y}$ are easier to access information and are more educated, the teachers are still unable to compete with the existing knowledge of Baby Boomers. The study by Mohd Faeez et. al (2017) claimed that there are teachers who do not consider training programs as important. Therefore, the experience and knowledge that Baby Boomer teachers have, should be passed on to the next generation in order for the organization to continue to be successful and competitive in the future (Gibson et. al, 2010). At this point, most Baby Boomers teachers are entering the retirement phase, so organizations or schools need to put in place appropriate strategies and mechanisms to help Baby Boomers teachers share or pass on their expertise, skills and knowledge to the next generation of teachers (Burch\& Strawderman, 2014).

The levels of professional development of the teachers being studied refer to the information on the different levels of knowledge in baby Boomers, Gen X teachers, and Gen $\mathrm{Y}$ teachers as a result of professional development activities derived from their organization's human resource management. The level of assessment is based on the response, learning, behavior and organizational outcomes that each teacher receives in the activity. Aspect of response is the emotional response of the individual to the activity attended. Aspect of learning is evaluated based on the acquisition of methodological knowledge, procedures and knowledge as well as change of attitude through the activities undertaken. The behavioral aspect is the assessment of content activity application to the daily tasks; and the outcome aspect is the assessment on the impact of organizational training that involves time and cost invested whether beneficial with what have been earned by the organization (Grohmann \& Kauffeld, 2013).

The findings show that Baby Boomers teachers have higher levels of professional development than Gen X and Gen Y teachers. This study is in line with findings from Newberry (2013), which stated that the Baby Boomers are more interested in traditional learning led by a teacher using lecture methods enhanced by hands-on activities such as courses and workshops. Based on this study, it was found that most of the activities attended by the respondents were in the form of courses and workshops. Therefore, the findings show that Gen $\mathrm{Y}$ teachers have a significantly higher level of professional development than Baby Boomers and Gen X teachers. A study by Cruz (2014) showed that Gen Y workers are more interested in up-to-date technology learning, cooperation and collaboration in their professional development. This could indicate that courses and workshops are less suitable for Gen Y teachers.

The findings clearly show that each teacher has different needs and wants in the learning process. Generation gaps can be one of the factors that cause this difference (Ramkumar \&Valdehi, 2013). The existence of multi generation teachers in schools can lead to problems in school management because according to Kirton (2014), organizations that do not have effective strategies in addressing inter-generation challenges that focus on individual needs will cause the organization to become weak, conflicted and lose valuable opportunities. Therefore, the role of the organization is to design professional 
development activities in line with the capabilities and needs of its own generation factors to ensure that all teachers will have the impact of the professional development activities organized.

A study by Elle and Elle (2017) stated that Baby boomers' teachers are more motivated if they are involved in discussions about their teaching such as in seminars or teaching courses. Unlike the Gen X teachers who are more motivated if their professional development activities allow them to engage and make decisions such as holding workshops in the form of problem-solving tasks since they are more self-reliant (Tan\& Fauziah, 2012). On the other hand, Gen Y is more motivated when the organized professional development involves collaboration and technology (Behrstock \& Clifford, 2009). In addition, Gen $Y$ teachers do the job with ease and fun; have the ability to perform various tasks; and are also comfortable to use the social media (Ellen \& Ellen, 2017). This proves that Gen Y teachers prefer their professional development activities to be more informal.

Holistically, this study has drawn attention to significant cultural differences related to generations, which may raise critical challenges to strategies and policies in the management of human resources. This is because successful professional development depends on successful communication that can effectively disseminate information between teachers, administrators and personalities involved in human resource management (Marston, 2010). As such, it is important to look at the features and characteristics of each generation when developing professional development activities and programs for each generation of teachers in order to create a positive impact. In addition, it can avoid wastage of time and money invested by the ministry in strengthening the professional development of teachers.

The related parties should also look into this issue carefully in order to avoid conflicts among teachers which can lead to schism in the organization. Communication, a balanced career and life, the use of technology are critical issues in the delivery of information to multi generation organization (Hillman, 2014). Effective leaders need to understand the differences between generations (Arsenault, 2004) and, in turn, exposes all teachers to this multi generation concept. This is important so as to establish strong brotherhood and unity within the organization. For example, Baby Boomers are generally satisfied with existing recognition training programs, while Gen X and Gen Y groups are seeking more recognition programs for their work achievements (Hillman, 2014). Hence, Baby Boomers teachers should support and motivate other generations of teachers and do not just show indifference to the program organized. It is important for schools to maintain the values of cooperation, respect and tolerance among teachers.

This study is hoped to provide guidance to teachers who are facing students of the alpha generation. This alpha generation is the first generation to survive in the 21 st century, and they will be the most technologically advanced generation. So, can we as educators still rely on our existing skills and expertise to educate students who are living in the age of advanced development? The solution is through effective teacher professional development to enhance skills and expertise in line with the present scenario. Teachers 
also have learning styles just like students. Therefore, the teacher's learning must be compatible with the teacher's own needs.

\section{CONCLUSION}

Overall, this study was conducted to find out the level of professional development that teachers receive across generations. The findings show that there was a significant level of difference across generations. Therefore, the issues discussed are expected to help improve the quality of professional development to be more effective and meaningful across all levels of teachers. As a teacher, the responsibility is to ensure student achievement; it should play an important role in ensuring that professional development of teachers meets the educational needs of students. Hence, professional development must be in line with teachers' strengths and weaknesses to promote leadership, strengthen their potential, and reduce aspects of pedagogical practice which lack quality to achieve the ultimate goal of student achievement and thus produce a quality education system in line with the changing times.

\section{ACKNOWLEDGEMENT}

This research was support by RIMC-UTLC UUM, COD S.O: 14510

\section{REFERENCES}

Arsenault, P.M. (2004). Validating generational differences: A legitimate diversity and leadership issue, Leadership \& Organization Development Journal, 25(2), 124-141.

Breiburd, S. (2018). Supporting novice teachers: Tips for z-friendly professional development. Retrieved from https://goo.gl/EExY6M.

Behrstock, E., \& Clifford, M. (2009). Leading gen y teachers: Emerging strategies for school leader. Retrieved from http://www.TQsource.org.

Burch, R., \& Strawderman, L. (2014). Leveraging generational differences to reduce Knowledge transfer and retention issues in public administration. PAR, 3(2), 20-32.

Carter, T. (2018). Preparing generation $\mathrm{Z}$ for the teaching profession. SRATE Journal, $27(1), 1-8$.

Cruz, M. C. (2014). Generation Y workplace needs and preferred leadership styles (Unpublished master thesis). Universiti Pepperdine.

Desai, S. (2016). Gen X teacher, millenial student. Retrieved from http://blogs.hct.ac.ae/foundations/2016/10/31/gen-X-teacher-millennial-students/.

Eller, J. F., \& Eller, S. A. (2017). Appropriate generating support: What new principals need to know about working with baby boomers, Generation $X$, and millennial. Retrieved www.naesp.org.com.

Gibson, J. W., Jones, J. P., Cella, J., Clark, C., Eipstein, A., \& Haselberger, J. (2010). Ageism and the Baby Boomers: Issues Challenge and the TEAM approach. Contemporary Studies in Issues in Education, 3(1), 53-60. 
Grohmann, A., \& Kauffeld, S. (2013). Evaluating Training Programs: Development and Correlates of the Questionnaire for Professional Training Evaluation. International Journal of Training and Development, 17, 135-155.

Hillman, D. R. (2014). Understanding multigenerational work-value conflict resolution. Journal of Workplace Behavioral Health, 29,240-257.

Higginbottom, K. (2016). The challenge of managing a-multigeneration workforce. Retrieved from https://www.forbes.com/sites/karenhigginbottom/2016/03/17/thechallenges-of-managing-a-multi-generational-workforce/\#6561bd2b7d6a.

Hugman, R. (2005). Looking back: The view from here. The British Journal of Social Work, 35, 609-620.

Hunt, J. E., \& Tucciarone, J. (2011). The challenges and opportunities of teaching "Generation Y". Journal of Graduate Medical Education, 3(4), 458-461.

Ilias, M. F., Rashed, Z. N., Razali, A. S. M., \& Sulaiman, M. S. (2017, September).Penilaian terhadap pelaksanaan program latihan guru-guru sekolah rendah agama Jabatan Agama Islam Selangor [Evaluation of the implementation of the training program of the Selangor Islamic Religious Department's primary school teachers] .Seminar Kajian Inovasi dan Pengurusan kali ke-4 [Seminar Innovation and Management Review no 4], Institut Latihan Malaysian, Bangi, Selangor, Malaysia.

James, J. B., Swanberg, J. E., \& McKenchnie, S. P. (2007). Generational differences in perceptions older workers capabilities. Retrieved from https://www.bc.edu/content/dam/files/research_sites/agingandwork/pdf/publications/IB1 2_OlderWorkersCapability.pdf.

Jamil, H., Abd. Razak, N., Raju, R., \& Mohamed, A. R. (2014). Teacher professional development in Malaysia: Issues and challenge. In Africa-Asia university dialogue for educational development report of the international experience sharing seminar: actual status and issues of teacher professional development (pp. 85-102). CICE Series 5. Hiroshima: Hiroshima University.

Kian, T. S., \& Yusof,W. F. W. (2012, Dis). Generation $X$ and $Y$ and their work motivation. Proceeding International Conference of Technology Management, Business and Entrepreneurship, Melaka, Malaysia.

Kirton, H. (2014). Prepare for the " $4 G$ " age diverse workforce. Retrieved from https://www.peoplemanagement.co.uk/

Klassen, R. M., \& Chiu, M. M. (2010). Effects on teachers' self-efficacy and job satisfaction: Teacher gender, years of experience, and job stress. Journal of Educational Psychology, 102(3), 741.

Marston, C. (2010). Employee training \& development across the generation. Retrieved from https://trainingindustry.com/articles/strategy-alignment-and-planning/employeetraining-and-development-across-the-generations/. 
Masri, R., Ahmad, A., \& Rani, R. A. (2018). Maslow theory in the contexts of fulfilling basic needs and its role in rising organizational performances: Study and Islamic perspective. Jurnal Hadhari, 10(1), 1-28

Mukunder, J., Nimehchilsalem, V., \& Hajimohammadi, R. (2011). How Malaysian school teachers view professional development? Journal of International Education Research, 7(2), 39-46.

Newberry, S. (2013). Bridging the gap: identifying perceptions of effectives teaching method for age 50++ baby boomers learner (Unpublished doctoral dissertation). Universiti Capella.

Ramkumar, N., \& Valdehi, P, V. (2013). Examining the relationship between positive aura, interpersonal effectiveness and generation gap. Journal of Contemporary Research in Management, 8(4), 61-74.

Sayers, R. (2007). The right staff from x to y. Library Management, 28(8), 474-487.

Schroer, W. J. (2008). Generations x, y, z and the others. The Journal of the Household Goods Forwarders Association of America, 40, 9-11.

Seipert, K., \& Bahgrust, T. (2014). Contrasting work values of Baby Boomers and generation X rural public school principals. Journal of Public Administration Quarterly, 38(3), 347-370.

Ting, H., Lim, T. Z., Cyril de Run, E., Koh, H., \& Murni Shahdan. (2018). Are we baby boomers, gen $\mathrm{x}$ and gen $\mathrm{y}$ ? A qualitative inquiry into generation cohorts in Malaysia. Kasetsart Journal of Social Sciences. 39(1), 109-115.

Valcour, M. (2013). Hitting the intergenerational sweet spot. HBR Blog Network. Retirieved from http://blogs.hbr.org/2013/05/hitting-the-intergenerational/.

Yang, J., Yu, C-S., \& Wu, J. (2018). Work values across generations in China. Chinese Management Studies, 12(3),486-505.

Zemke, R., Raines, C., \& Filipczak, B. (2000). Generations at work: Managing the clash of veterans, boomers, xers, and nexters in your workplace. New York: AMACOM. 